\title{
PENGARUH RETURN ON ASSET (ROA) DAN UKURAN PERUSAHAAN TERHADAP FINANCIAL DISTRESS PADA PERUSAHAAN SUB SEKTOR KIMIA YANG TERDAFTAR DI BURSA EFEK INDONESIA
}

\author{
Jaka Maulana, Suhartati \\ D4 Akuntansi Keuangan, Politeknik Pos Indonesia \\ jakamaulana@poltekpos.ac.id, suhartaty20@gmail.com
}

\begin{abstract}
ABSTRAK
Dalam mendirikan suatu perusahaan tentunya mempunyai tujuan untuk mendapatkan keuntungan, tetapi juga akan mengalami penurunan kondisi keuangan. Sehingga banyak berbagai perusahaan yang mengalami kebangkrutan dikarenakan perusahaan tersebut kurang efektif dan efisien dalam mengelola laporan keuangan. Penelitian ini bertujuan untuk mengetahui dan menganalisis pengaruh return on asset (ROA) dan ukuran perusahaan terhadap financial distress. Metode yang digunakan dalam penelitian ini adalah metode kuantitatif dengan data sekunder dan jenis perumusan masalah asosiatif yang memiliki hubungan sebab akibat. Populasi dalam penelitian ini adalah perusahaan Sub Sektor Kimia yang terdaftar di Bursa Efek Indonesia tahun 2016-2019. Berdasarkan kriteria yang ada, pengambilan sampel dilakukan dengan teknik purposive sampling, sampel yang diperoleh 8 perusahaan dengan total sampel 32 data. Pengujian hipotesis dalam penelitian ini menggunakan uji normalitas data, analisis korelasi product moment, analisis korelasi berganda, analisis regresi linier berganda, analisis koefisien determinasi, uji t-test, dan uji f-test. Hasil penelitian ini menunjukkan bahwa secara parsial return on asset (ROA) tidak memiliki pengaruh terhadap financial distress dan ukuran perusahaan memiliki pengaruh positif yang signifikan terhadap financial distress. Secara simultan return on asset (ROA) dan ukuran perusahaan memiliki pengaruh positif yang signifikan terhadap financial distress.

Kata Kunci : Return On Asset, Ukuran Perusahaan, Financial Distress
\end{abstract}

\begin{abstract}
In establishing a company, of course, you have the goal of making a profit, but it will also experience a decline in financial condition. So that many companies have gone bankrupt because these companies are less effective and efficient in managing financial reports. This study aims to determine and analyze the effect of return on assets (ROA) and company size on financial distress. The method used in this research is a quantitative method with secondary data and the type of formulation of associative problems that have a causal relationship. The population in this study were Chemical Sub-Sector companies listed on the Indonesia Stock Exchange in 2016-2019. Based on the existing criteria, the sample was taken by using purposive sampling technique, the sample obtained by 8 companies with a total sample of 32 data. Hypothesis testing in this study uses data normality test, product moment correlation analysis, multiple correlation analysis, multiple linear regression analysis, determination coefficient analysis, $t$-test, and f-test. The results of this study indicate that partial return on assets (ROA) has no effect on financial distress and firm size has a significant positive effect on financial distress. Simultaneously, return on assets (ROA) and company size have a significant positive effect on financial distress.Keywords:Return On Assets, Company Size,Financial Distress. Keywords: Return On Assets, Company Size, Financial Distress
\end{abstract}




\section{PENDAHULUAN}

Semakin berkembangnya dunia usaha dari tahun ketahun sampai saat ini, menjadikan persaingan yang sangat ketat diantara perusahaan kecil maupun perusahaan besar. Suatu perusahaan didirikan dengan tujuan untuk mendapat keuntungan, tetapi disetiap perusahaan pasti ada masalah jatuh bangun dikarenakan hal tersebut sudah biasa yang akan dihadapi oleh perusahaan. Sehingga banyak berbagai perusahaan yang mengalami kebangkrutan dikarenakan perusahaan tersebut kurang efektif dan efisien dalam mengelola laporan keuangan. Dilihat melalui laporan keuangan dapat menunjukkan kebangkrutan pada perusahaan, karena laporan keuangan sangat penting untuk menunjukkan kinerja sebuah perusahaan tersebut.

Berdasarkan (Berita 2018) berita CNBC Indonesia di Jakarta pada tanggal 13 September 2018 pukul 15.36 WIB, PT Barito Pasific Tbk (BRPT) pada periode sepanjang semester I-2018 mengalami penurunan laba bersih mencapai 46,68\% menjadi US\$ 41,64 juta. Penurunan laba perusahaan ini disebabkan oleh turunnya kontribusi dari entitas anak usahanya dan refinancing sejumlah utang perusahaan. Seperti yang dilansir (Berita 2019) berita kontan.co.id pada hari Rabu, 20 September 2019 mengalami profitabilitas menurun yaitu "pada Return On Asset (ROA) turun ke 2,48\% disebabkan adanya penurunan kinerja laba sebelum pajak dan juga permintaan kredit yang mini." Selanjutnya seperti yang dilansir (Meiliana 2019) melalui berita kompas.com pada tanggal 15 April 2019 pukul 17.13 WIB, "bahwa ukuran suatu perusahaan tak hanya dilihat dari besarnya laba dan aset tetapi juga nilainya perlu dibangun dalam membesarkan perusahaan. Fenomena tersebut menunjukkan adanya revolusi dalam dunia bisnis dimana nilai perusahaan bisa mengalahkan besarnya laba dan aset.

Untuk menghindari penurunan kondisi keuangan atau kebangkrutan perusahaan harus melakukan pengelolaan yang tepat, dalam hal ini return on asset (ROA) dan ukuran perusahaan diperlukan pengelolaan yang efektif dan kebutuhan yang tepat dalam penggunaan, pemeliharaan, maupun pencatatannya. Sedangkan pada perusahaan Sub Sektor Kimia yang terdaftar di Bursa Efek Indonesia, dalam hal pengelolaan return on asset (ROA) dan ukuran perusahaan kurang efektif dan kurang efisien karena perusahaan tidak mampu mengelola dan menjaga kestabilan kinerja keuangan sehingga menyebabkan perusahaan mengalami kerugian operasional dan kerugian bersih untuk tahun yang berjalan.

Dari latar belakang yang telah dijabarkan, penelitian ini dilakukan untuk mengetahui apakah terdapat pengaruh antara return on asset (ROA) dan ukuran perusahaan terhadap financial distress baik secara parsial maupun simultan? Terdapat beberapa penelitian terdahulu yang digunakan untuk menjadi referensi penelitian ini yaitu (Sopian 2015) yang berjudul Pengaruh Rasio Keuangan dan Ukuran Perusahaan terhadap Financial Distress, dan penelitian (Fridayanthie 2016) yang berjudul Pengaruh Current Ratio, Return On Asset, Ukuran Perusahaan dan Sales Growth terhadap Financial Distress.

\section{KAJIAN PUSTAKA}

\section{Return On Asset (ROA)}

(Hery 2016) menyatakan "return on asset (ROA) adalah rasio yang mengukur tingkat pengembalian dari bisnis atas seluruh aset yang ada. Atau rasio ini menggambarkan efisiensi pada dana yang digunakan dalam perusahaan."

(Hery 2016) menyatakan rumus Return On Asset (ROA) yang dapat dihitung adalah sebagai berikut :

Ukuran Perusahaan Return On Asset $=\frac{\text { Laba Bersih }}{\text { Total Aset }}$ 
(Bambang Riyanto 2016) menyatakan "Ukuran perusahaan adalah besar kecilnya perusahaan dilihat dari nilai equity, nilai penjualan, atau nilai aktiva."

Ukuran perusahaan dapat dihitung menggunakan logaritma total asset perusahaan menurut (Bambang Riyanto 2016). Berikut adalah rumusnya :

\section{Financial Distress}

$$
U P=\text { Ln Total Asset }
$$

Menurut Platt dan Platt (2002) dalam (Sopian 2015) menyatakan "Financial distress adalah kondisi keuangan perusahaan pada tahap penurunan sebelum terjadi likuidasi atau kebangkrutan pada perusahaan."

Menurut (Sopian 2015) menyatakan berikut adalah formula Altman Z-score :

\begin{tabular}{|r|}
\hline$Z-$ score $=0,717 T 1+0,847 T 2+3,107 T 3+0,420 T 4+0,998 T 5$ \\
\hline
\end{tabular}

\section{Rumus Financial Distress}

Penafsiran hasil Z-score yang didapatkan adalah sebagai berikut :

a. Z-score $>2,60$

Berdasarkan laporan keuangan, perusahaan dianggap aman atau perusahaan yang tidak bangkrut.

b. $\quad 1,1 \leq \mathrm{Z}$-score $<2,60$

Terdapat kondisi keuangan di suatu bagian yang membutuhkan perhatian khusus yaitu termasuk grey area (tidak dapat ditentukan apakah perusahaan sehat ataupun mengalami kebangkrutan).

c. Z-score $<1,1$

Perusahaan berpotensi kuat akan mengalami kebangkrutan, termasuk perusahaan yang bangkrut.

\section{METODE PENELITIAN}

\section{Jenis Penelitian}

Metode yang digunakan dalam penelitian ini adalah metode penelitian kuantitatif dengan jenis penelitian asosiatif dengan bentuk hubungan kausal. Hubungan kausal merupakan hubungan yang bersifat sebab akibat.

\section{Operasionalisasi Variabel}

Berdasarkan judul penelitian ini yaitu "Pengaruh Return On Asset (ROA) dan Ukuran Perusahaan Terhadap Financial Distress Pada Perusahaan Sub Sektor Kimia yang terdaftar di Bursa Efek Indonesia" maka variabel dalam penelitian ini adalah variabel independen return on asset (ROA) $\left(\mathrm{X}_{1}\right)$, ukuran perusahaan $\left(\mathrm{X}_{2}\right)$ dan variabel dependen Financial Distress (Y). Berikut adalah tabel operasionalisasi variabel :

\begin{tabular}{|c|c|c|c|}
\hline \multicolumn{4}{|c|}{ Operasionalisasi Variabel } \\
\hline Variabel & Indikator & $\begin{array}{l}\text { Skala } \\
\text { Ukur }\end{array}$ & Alat Analisis \\
\hline $\begin{array}{ll}\mathrm{X}_{1}: & \text { Return } \\
\text { On } \quad \text { Asset } \\
(\mathrm{ROA})\end{array}$ & $\begin{array}{l}\qquad R O A=\frac{\text { Laba Bersih }}{\text { Total Aset }} \\
\text { 1. Laba Bersih } \\
\text { 2. Total Asset } \\
\text { Sumber : (Hery 2016) }\end{array}$ & Rasio & $\begin{array}{l}\text { 1. Uji Normalitas Data } \\
\text { 2. Analisis Korelasi Product } \\
\text { Moment } \\
\text { 3. Analisis Korelasi Berganda } \\
\text { 4. Analisis Regresi Linier } \\
\text { Berganda } \\
\text { 5. Analisis Koefisien Determinasi } \\
\text { 6. Uji T-test } \\
\text { 7. Uji F-test }\end{array}$ \\
\hline $\begin{array}{l}\mathrm{X}_{2}: \text { Ukuran } \\
\text { Perusahaan }\end{array}$ & $\begin{array}{l}U P=\text { Ln Total Asset } \\
\text { 1. Total Asset }\end{array}$ & Rasio & $\begin{array}{l}\text { 1. Uji Normalitas Data } \\
\text { 2. Analisis Korelasi Product } \\
\text { Moment }\end{array}$ \\
\hline
\end{tabular}




\begin{tabular}{|c|c|c|c|}
\hline & $\begin{array}{l}\text { Sumber :(Bambang Riyanto } \\
\text { 2016) }\end{array}$ & & $\begin{array}{l}\text { 3. Analisis Korelasi Berganda } \\
\text { 4. Analisis Regresi Linier } \\
\text { Berganda } \\
\text { 5. Analisis Koefisien Determinasi } \\
\text { 6. Uji T-test } \\
\text { 7. Uii F-test }\end{array}$ \\
\hline $\begin{array}{l}\text { Y: Financial } \\
\text { Distress }\end{array}$ & $\begin{array}{l}\text { Z-Score }= \\
\text { 0,717T1+0,847T2+3,107T3+ } \\
\text { 0,420T4+0,998T5 } \\
\text { 1. Total Asset } \\
\text { 2. Modal Kerja } \\
\text { 3. Laba Ditahan } \\
\text { 4. Laba Sebelum Bunga dan } \\
\text { Pajak } \\
\text { 5. Ekuitas Pemegang Saham } \\
\text { 6. Total kewajiban } \\
\text { 7. Penjualan } \\
\text { Sumber : (Sopian 2015) }\end{array}$ & Rasio & $\begin{array}{l}\text { 1. Uji Normalitas Data } \\
\text { 2. Analisis Korelasi Product } \\
\text { Moment } \\
\text { 3. Analisis Korelasi Berganda } \\
\text { 4. Analisis Regresi Linier } \\
\text { Berganda } \\
\text { 5. Analisis Koefisien Determinasi } \\
\text { 6. Uji T-test } \\
\text { 7. Uji F-test }\end{array}$ \\
\hline
\end{tabular}

Sumber : Data diolah penulis (2020)

\section{Teknik Pengumpulan Data}

Teknik pengumpulan data yang digunakan dalam penelitian ini adalah dengan menggunakan teknik dokumentasi. Studi dokumentasi ini berupa pengumpulan data-data tertulis secara objektif dari materi dan teori, peraturan atau surat keputusan penting serta berbagai informasi dan data terkait yang dianggap dapat mendukung penulis mengembangkan penelitian.

Berdasarkan kebutuhan dalam pengambilan data-data dalam penelitian, maka penelitian ini penulis menggunakan metode pengumpulan data sekunder. Penulis mengambil data-data sekunder berupa dokumen berbentuk laporan keuangan yang terdiri dari laporan laba rugi dan laporan posisi keuangan pada perusahaan Sub Sektor Kimia yang terdaftar di Bursa Efek Indonesia periode 2016-2019 dimana data tersebut diakses di website resmi Bursa Efek Indonesia.

\section{Populasi dan Sampel}

Populasi dalam penelitian ini adalah laporan keuangan perusahaan Sub Sektor Kimia yang terdaftar di Bursa Efek Indonesia. Jumlah populasi yang terdapat pada perusahaan Sub Sektor Kimia yang terdaftar di Bursa Efek Indonesia adalah 13 perusahaan selama 4 periode. Jadi, total jumlah data yang diperoleh adalah sebanyak 52 data. Akan tetapi tidak semua bagian populasi bisa menjadi objek penelitian, maka perlu dilakukan pengambilan sampel.

Sampel dalam penelitian ini adalah laporan keuangan perusahaan Sub Sektor Kimia yang terdaftar di Bursa Efek Indonesia. Teknik sampling dalam penelitian ini adalah nonprobability sampling yang digunakan adalah purposive sampling. Sampel yang memenuhi kriteria sebanyak 8 perusahaan dengan periode yang diambil selama 4 tahun, jadi jumlah data yang diperoleh adalah 32 data.

\section{Teknik Analisis Data}

Penelitian ini menggunakan tujuh teknik analisis data yaitu uji normalitas data, analisis korelasi product moment, analisis korelasi berganda, analisis regresi linier berganda, analisis koefisien determinasi, uji t-test, dan uji f-test. Data Diolah dengan Program IBM SPSS Statistics Versi 25.0 (2020)

\section{HASIL DAN PEMBAHASAN Uji Normalitas Data}


Uji normalitas dilakukan untuk menguji apakah dalam model regresi variabel independen dan variabel dependen atau keduanya mempunyai distribusi normal atau tidak. Dasar pengambilan keputusan dalam penelitian ini adalah bila nilai signifikan $>0,05$, maka data berdistribusi normal dan jika nilai signifikansi $<0,05$, maka data tidak berdistribusi normal.

Berdasarkan atas pengolahan data yang dilakukan peneliti dalam penelitian ini, maka hasil uji normalitas dapat terlihat pada tabel berikut :

\section{One-Sample Kolmogorov-Smirnov Test}

\section{Hasil Uji Normalitas Data}

\begin{tabular}{lll} 
& & Unstandardized Residual \\
\hline $\mathrm{N}$ & & 32 \\
\hline Normal Parameters & & \\
Most Extreme Differences & Mean & .0000000 \\
\cline { 2 - 3 } & Std. Deviation & .52811221 \\
\cline { 2 - 3 } & Absolute & .115 \\
\cline { 2 - 3 } & Positive & .115 \\
\cline { 2 - 3 } Test Statistic & & -.068 \\
\hline Asymp. Sig. (2-tailed) & & .115 \\
\hline
\end{tabular}

a. Test distribution is Normal.

b. Calculated from data.

c. Lilliefors Significance Correction.

d. This is a lower bound of the true significance.

Sumber: Data Diolah dengan Program IBM SPSS Statistics Versi 25.0 (2020)

Dari hasil uji normalitas yang dilakukan bahwa setiap variabel memiliki nilai Asymtotic Significanted (2-tailed) sebesar 0,200 dimana hal tersebut menunjukan jika nilai tersebut lebih besar dari nilai 0,05 dinyatakan terdistribusi normal. Dimana hal tersebut berdasar teori menurut (P. D. Sugiyono 2017) yang menyatakan "jika nilai signifikan lebih besar sama dengan $(>)$ 0,05 maka data tersebut berdistribusi normal". Hasil uji normalitas pada penelitian ini menunjukan 0,200>0,05 maka dengan demikian data tersebut dinyatakan berdistribusi normal.

\section{Analisis Korelasi Product Moment}

Analisis korelasi product moment digunakan untuk memastikan kuat atau lemahnya hubungan antara return on asset $(\mathrm{ROA})\left(\mathrm{X}_{1}\right)$ dan ukuran perusahaan $\left(\mathrm{X}_{2}\right)$ secara parsial terhadap financial distress (Y) maka dari itu dilakukan pengelolaan data dengan menggunakan IBM SPSS Statistic 25.0 dengan hasil sebagai berikut :

\section{Correlations}

Hasil Analisis Korelasi Product Moment

\begin{tabular}{lll|l|l} 
& & ROA & $\begin{array}{l}\text { Ukuran_Perusa } \\
\text { haan }\end{array}$ & $\begin{array}{l}\text { Financial_Distr } \\
\text { ess }\end{array}$ \\
\hline ROA & Pearson Correlation & 1 & -.087 & .174 \\
\cline { 2 - 5 } & Sig. (2-tailed) & & .634 & .341 \\
\cline { 2 - 5 } & $\mathrm{N}$ & 32 & 32 & 32 \\
\hline Ukuran_Perusahaan & Pearson Correlation & -.087 & 1 & .537 \\
\cline { 2 - 5 } & Sig. (2-tailed) & .634 & & .002 \\
\cline { 2 - 5 } & $\mathrm{N}$ & 32 & 32 & 32 \\
\hline Financial_Distress & Pearson Correlation & .174 & .537 & 1 \\
\hline
\end{tabular}




\begin{tabular}{ll|l|l|l}
\hline Sig. (2-tailed) & .341 & .002 & \\
\cline { 2 - 5 } $\mathrm{N}$ & 32 & 32 & 32 \\
\hline
\end{tabular}

Sumber: Data Diolah dengan Program IBM SPSS Statistics Versi 25.0 (2020)

Berdasarkan hasil pengolahan data korelasi product moment menggunakan IBM SPSS 25.0 dapat diketahui bahwa return on asset (ROA) $\left(\mathrm{X}_{1}\right)$ memiliki hubungan positif terhadap financial distress $(\mathrm{Y})$ sebesar 0,174 dengan tingkat hubungan yang sangat rendah karena berada pada rentan $0,00-0,199$. Sedangkan ukuran perusahaan $\left(\mathrm{X}_{2}\right)$ memiliki hubungan positif terhadap financial distress (Y) sebesar 0,537 dengan tingkat hubungan yang sedang berada pada rentan 0,40-0,599.

\section{Analisis Korelasi Berganda}

Korelasi ganda merupakan angka yang menunjukkan arah dan kuatnya hubungan antara dua variabel independen secara bersama-sama atau lebih dengan satu variabel dependen. Dalam penelitian ini analisis korelasi berganda digunakan untuk menunjukkan arah dan kuatnya hubungan return on asset (ROA) dan ukuran perusahaan terhadap financial distress pada perusahaan sub sektor kimia yang terdaftar di Bursa Efek Indonesia. Dengan menggunakan IBM SPSS Statistic 25.0, maka terdapat hasil seperti berikut:

\begin{tabular}{|c|c|c|c|c|}
\hline \multirow{2}{*}{\multicolumn{5}{|c|}{ Hasil Analisis Korelasi Ganda }} \\
\hline & & & & \\
\hline Model & $\mathrm{R}$ & R Square & $\begin{array}{l}\text { Adjusted } \\
\text { Square }\end{array}$ & Std. Error of the Estimate \\
\hline 1 & $.581^{\mathrm{a}}$ & .337 & .291 & .54602 \\
\hline
\end{tabular}

a. Predictors: (Constant), Ukuran_Perusahaan, ROA

b. Dependent Variable: Financial_Distress

Sumber: Data Diolah dengan Program IBM SPSS Statistics Versi 25.0 (2020)

Dari hasil diatas, dapat dilihat bahwa hasil $\mathrm{R}$ sebesar 0,581 menunjukkan return on asset $(\mathrm{ROA})\left(\mathrm{X}_{1}\right)$ dan ukuran perusahaan $\left(\mathrm{X}_{2}\right)$ terhadap financial distress $(\mathrm{Y})$ secara simultan atau bersama-sama memiliki hubungan yang sedang terhadap financial distress karena berada pada rentan 0,40-0,599.

\section{Analisis Regresi Linier Berganda}

Analisis ini digunakan untuk mengetahui arah pengaruh antara variabel independen dengan variabel dependen apakah masing-masing variabel independen berpengaruh positif atau negatif dan untuk memprediksi nilai dari variabel dependen apabila nilai independen mengalami kenaikan atau penurunan. Berikut ini adalah hasil dari analisis regresi linear berganda yang telah dilakukan oleh peneliti:

\section{Coefficients $^{\mathbf{a}}$}

\section{Hasil Analisis Regresi Linier Berganda}

\begin{tabular}{|c|c|c|c|c|c|c|}
\hline \\
\hline \multirow{2}{*}{\multicolumn{2}{|c|}{ Model }} & \multicolumn{2}{|c|}{ Unstandardized Coefficients } & \multirow{2}{*}{$\begin{array}{l}\text { Standardized } \\
\text { Coefficients } \\
\text { Beta }\end{array}$} & \multirow[b]{2}{*}{$\mathrm{t}$} & \multirow[b]{2}{*}{ Sig. } \\
\hline & & $\mathrm{B}$ & Std. Error & & & \\
\hline \multirow[t]{3}{*}{1} & (Constant) & -5.445 & 1.933 & & -2.817 & .009 \\
\hline & ROA & .029 & .020 & .222 & 1.466 & .153 \\
\hline & Ukuran_Perusahaan & .263 & .072 & .556 & 3.664 & .001 \\
\hline
\end{tabular}

a. Dependent Variable: Financial_Distress

Sumber: Data Diolah dengan Program IBM SPSS Statistics Versi 25.0 (2020)

Dari hasil pengolahan data menggunakan SPSS 25.0, dapat diketahui nilai konstanta (a) sebesar $-5,446$, dan nilai koefisien regresi $\left(b_{1}\right) X_{1}$ sebesar 0,029 serta nilai koefisien regresi $\left(b_{2}\right) X_{2}$ sebesar 0,263 . Sehingga apabila dimasukkan ke dalam persamaan regresi linear berganda, maka diperoleh: 


$$
\begin{aligned}
& Y=a+b_{1} X_{1}+b_{2} X_{2} \\
& Y=-5,445+0,029 X_{1}+0,263 X_{2}
\end{aligned}
$$

Dimana :

$\mathrm{Y} \quad=$ Financial Distress

a $\quad=$ Konstanta

$\mathrm{b}_{1} \mathrm{~b}_{2} \quad=$ Koefisien Regresi

$\mathrm{X}_{1} \quad=$ Return On Asset (ROA)

$\mathrm{X}_{2} \quad=$ Ukuran Perusahaan

Dari persamaan tersebut, dapat diartikan sebagai berikut:

1. Jika variabel return on asset $(\mathrm{ROA})\left(\mathrm{X}_{1}\right)$ dan financial distress $\left(\mathrm{X}_{2}\right)$ nilainya adalah 0 , maka nilai variabel financial distress (Y) adalah sebesar konstanta atau sebesar $-5,445$.

2. Koefisien regresi variabel return on asset $(\mathrm{ROA})\left(\mathrm{X}_{1}\right)$ sebesar 0,029 artinya jika variabel independen lain nilainya tetap dan return on asset (ROA) $\left(\mathrm{X}_{1}\right)$ mengalami kenaikan 1 satuan, maka financial distress (Y) akan mengalami kenaikan sebesar 0,029. Karena koefisien bernilai negatif maka terjadi pengaruh antara return on asset (ROA) $\left(\mathrm{X}_{1}\right)$ terhadap financial distress (Y). Jadi, kenaikan return on asset (ROA) ( $\left.\mathrm{X}_{1}\right)$ mengakibatkan kenaikan pada financial distress $(\mathrm{Y})$.

3. Koefisien regresi variabel ukuran perusahaan $\left(\mathrm{X}_{2}\right)$ sebesar 0,263 , artinya jika variabel independen lain nilainya tetap dan ukuran perusahaan $\left(\mathrm{X}_{2}\right)$ mengalami kenaikan 1 satuan, maka financial distress (Y) akan mengalami penurunan sebesar 0,263. Karena koefisien bernilai positif maka terjadi pengaruh antara ukuran perusahaan $\left(\mathrm{X}_{2}\right)$ terhadap financial distress $(\mathrm{Y})$. Jadi, kenaikan ukuran perusahaan $\left(\mathrm{X}_{2}\right)$ mengakibatkan kenaikan pada financial distress $(\mathrm{Y})$.

\section{Koefisien Determinasi}

Dalam analisis korelasi terdapat suatu angka yang disebut dengan koefisien determinasi yang besarnya adalah kuadrat dari koefisien korelasi. Analisis korelasi determinasi digunakan untuk menguji seberapa besar kontribusi variabel return on asset (ROA) dan ukuran perusahaan mempengaruhi financial distress. Dengan menggunakan IBM SPSS 25.0 diperoleh hasil analisis koefisien determinasi sebagai berikut :

\section{Hasil Analisis Koefisien Determinasi}

Model Summary ${ }^{b}$

\begin{tabular}{ll|l|lr|l} 
Model & R & R Square & $\begin{array}{l}\text { Adjusted } \\
\text { Square }\end{array}$ & $R$ & Std. Error of the Estimate \\
\hline 1 & $.581^{\mathrm{a}}$ & .337 & .291 & .54602 \\
\hline
\end{tabular}

a. Predictors: (Constant), Ukuran_Perusahaan, ROA

b. Dependent Variable: Financial_Distress

Sumber: Data Diolah dengan Program IBM SPSS Statistics Versi 25.0 (2020)

Berdasakan tabel diatas dapat diketahui bahwa R Square adalah sebesar 0,337. Nilai ini dikenal dengan koefisien determinasi $(\mathrm{Kd})$ yang dapat dihitung sebagai berikut :

$\mathrm{Kd}=\mathrm{r} 2 \times 100 \%$

$\mathrm{Kd}=0,337 \times 100 \%$

$\mathrm{Kd}=33,7 \%$

Berdasarkan diperoleh R2 ( $\mathrm{R}$ Square) sebesar 0,337 atau 33,7\%. Hal ini menunjukkan bahwa persentase pengaruh variabel independen return on asset (ROA) $\left(\mathrm{X}_{1}\right)$ dan ukuran perusahaan $\left(\mathrm{X}_{2}\right)$ terhadap variabel dependen financial distress $(\mathrm{Y})$ adalah $33,7 \%$ yang berarti tingkat pengaruhnya rendah, sedangkan sisanya sebesar 66,3\% dipengaruhi oleh faktor lainnya yang tidak dimasukkan ke dalam penelitian ini.

Uji T-test

Pengujian hipotesis dalam penelitian ini menggunakan uji-t untuk menunjukan seberapa jauh pengaruh satu variabel independen secara individual dalam menerangkan 
variasi-variasi variabel dependen. Dalam penelitian ini menggunakan uji dua pihak (two tails test). Syarat penerimaan hipotesis menggunakan uji-t ini adalah sebagai berikut:

a. Ho ditolak, Ha diterima : apabila $t_{\text {hitung }} \geq t_{\text {tabel }}$ atau $-t_{\text {hitung }} \leq-t_{\text {tabel }}$ dengan tingkat signifikansi $<0,05(\alpha)$.

b. Ho diterima, Ha ditolak : apabila thitung $\leq t_{\text {tabel }}$ atau $-t_{\text {hitung }} \geq-t_{\text {tabel }}$ dengan tingkat signifikansi $>0,05(\alpha)$.

Hasil pengujian secara parsial dengan uji-t menggunakan aplikasi SPSS Statistic 25.0 dapat dilihat pada tabel berikut ini:

\section{Coefficients $^{\mathrm{a}}$}

Hasil Uji T-test

Model

$$
\begin{array}{l|l|l|l}
\text { Unstandardized Coefficients } & \begin{array}{l}
\text { Standardized } \\
\text { Coefficients }
\end{array} & \mathrm{t} & \text { Sig. }
\end{array}
$$

\begin{tabular}{l|l|l} 
B & Std. Error & Beta
\end{tabular}

\begin{tabular}{lll|l|l|l|l}
\hline 1 & -5.445 & 1.933 & & -2.817 & .009 \\
\cline { 2 - 7 } & Constant) & .029 & .020 & .222 & 1.466 & .153 \\
\cline { 2 - 7 } & .263 & .072 & .556 & 3.664 & .001 \\
\hline
\end{tabular}

a. Dependent Variable: Financial_Distress

Sumber: Data Diolah dengan Program IBM SPSS Statistics Versi 25.0 (2020)

Hasil uji t dengan menggunakan IBM SPSS Statistic 25.0 dalam tabel diatas antara variabel Return On Asset (ROA) $\left(\mathrm{X}_{1}\right)$ terhadap Financial Distress $(\mathrm{Y})$ menunjukkan bahwa nilai $t_{\text {hitung }}$ sebesar 1,466. Dengan melihat pada $t_{\text {tabel }}$ jumlah data $\mathrm{n}=32$ dan $(\mathrm{dk})=$ $\mathrm{n}-\mathrm{k}-1$ atau 32-2-1= 29 pada tingkat kesalahan $\alpha=0,05$ dengan pengujian dua pihak maka diperoleh $\mathrm{t}_{\text {tabel }}$ sebesar 2,045. Hal ini menunjukkan bahwa $\mathrm{t}_{\text {hitung }} \leq \mathrm{t}_{\text {tabel }}$ maka Ha ditolak dan Ho diterima dan dapat disimpulkan bahwa secara parsial tidak terdapat pengaruh antara return on asset (ROA) $\left(\mathrm{X}_{1}\right)$ terhadap financial distress $(\mathrm{Y})$ pada perusahaan Sub Sektor Kimia yang terdaftar di Bursa Efek Indonesia."

Sedangkan untuk variabel ukuran perusahaan $\left(\mathrm{X}_{2}\right)$ menunjukkan bahwa nilai thitung sebesar 3,664. Dengan melihat pada $t_{\text {tabel }}$ jumlah data $n=32$ dan $(\mathrm{dk})=\mathrm{n}-\mathrm{k}-1$ atau 32-2$1=29$ pada tingkat kesalahan $\alpha=0,05$ dengan pengujian dua pihak maka diperoleh $t_{\text {tabel }}$ sebesar 2,045. Hal ini menunjukkan bahwa $t_{\text {hitung }} \geq t_{\text {tabel }}$ maka Ha diterima dan Ho ditolak. Artinya secara parsial terdapat pengaruh positif yang signifikan antara ukuran perusahaan $\left(\mathrm{X}_{2}\right)$ terhadap financial distress $(\mathrm{Y})$ pada perusahaan Sub Sektor Kimia yang terdaftar di Bursa Efek Indonesia.

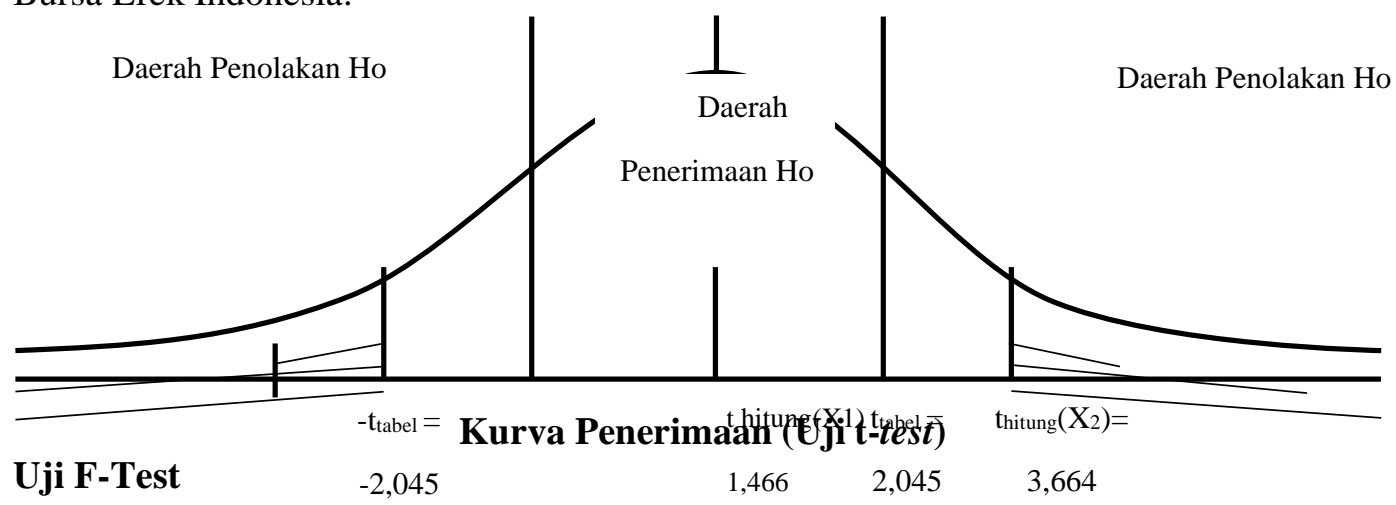

Uji F ini digunakan untuk mengetahui apakah variabel independen return on asset (ROA) $\left(\mathrm{X}_{1}\right)$ dan ukuran perusahaan $\left(\mathrm{X}_{2}\right)$ secara bersama-sama atau simultan berpengaruh secara signifikan terhadap variabel dependen financial distress $(\mathrm{Y})$. Uji F dilakukan dengan cara membandingkan $F_{\text {hitung }}$ dengan $F_{\text {tabel}}$, pedoman pengambilan keputusan hasil uji $\mathrm{f}$ adalah sebagai berikut:

a. Ha diterima, Ho ditolak : apabila probabilitas (signifikan) $<0,05(\alpha)$ atau $F_{\text {hitung }}>F_{\text {tabel. }}$. 
b. Ha ditolak, Ho diterima: apabila probabilitas (signifikan ) $>0,05(\alpha)$ atau $F_{\text {hitung }}<F_{\text {tabel. }}$. Berikut ini adalah tabel hasil dari uji F dengan menggunakan SPSS Statistic 25.0:

\section{Hasil Uji F-test}

ANOVA $^{\mathrm{a}}$

\begin{tabular}{|c|c|c|c|c|c|c|}
\hline Model & & $\begin{array}{l}\text { Sum of } \\
\text { Squares }\end{array}$ & $\mathrm{df}$ & Mean Square & $\mathrm{F}$ & Sig. \\
\hline \multirow[t]{3}{*}{1} & Regression & 4.396 & 2 & 2.198 & 7.372 & $.003^{b}$ \\
\hline & Residual & 8.646 & 29 & 298 & & \\
\hline & Total & 13.042 & 31 & & & \\
\hline
\end{tabular}

a. Dependent Variable: Financial_Distress

b. Predictors: (Constant), Ukuran_Perusahaan, ROA

Sumber: Data Diolah dengan Program IBM SPSS Statistics Versi 25.0 (2020)

Berdasarkan perhitungan SPSS versi 25.0, maka dapat nilai $F_{\text {hitung }}$ sebesar 7,372 dan signifikansi 0,003 dengan ( $\mathrm{dk}=\mathrm{n}-\mathrm{k}-1$ yaitu $32-2-1=29)$ dimana tingkat signifikansi $5 \%$ maka diperoleh nilai $F_{\text {tabel }}$ sebesar 2,045 sehingga $F_{\text {hitung }}>F_{\text {tabel }}(7,372>2,042)$ dan signifikansi $<0,05(0,003<0,05)$ maka Ha diterima dan Ho ditolak. Dengan demikian dapat disimpulkan bahwa secara simultan atau bersama-sama terdapat pengaruh positif yang signifikan antara Return On Asset (ROA) $\left(\mathrm{X}_{1}\right)$ dan Ukuran Perusahaan $\left(\mathrm{X}_{2}\right)$ terhadap Financial Distress (Y) pada Perusahaan Sub Sektor Kimia yang terdaftar di Bursa Efek Indonesia. Berikut adalah daerah penerimaan dan penolakan Ho apabila di sajikan dalam bentuk kurva:

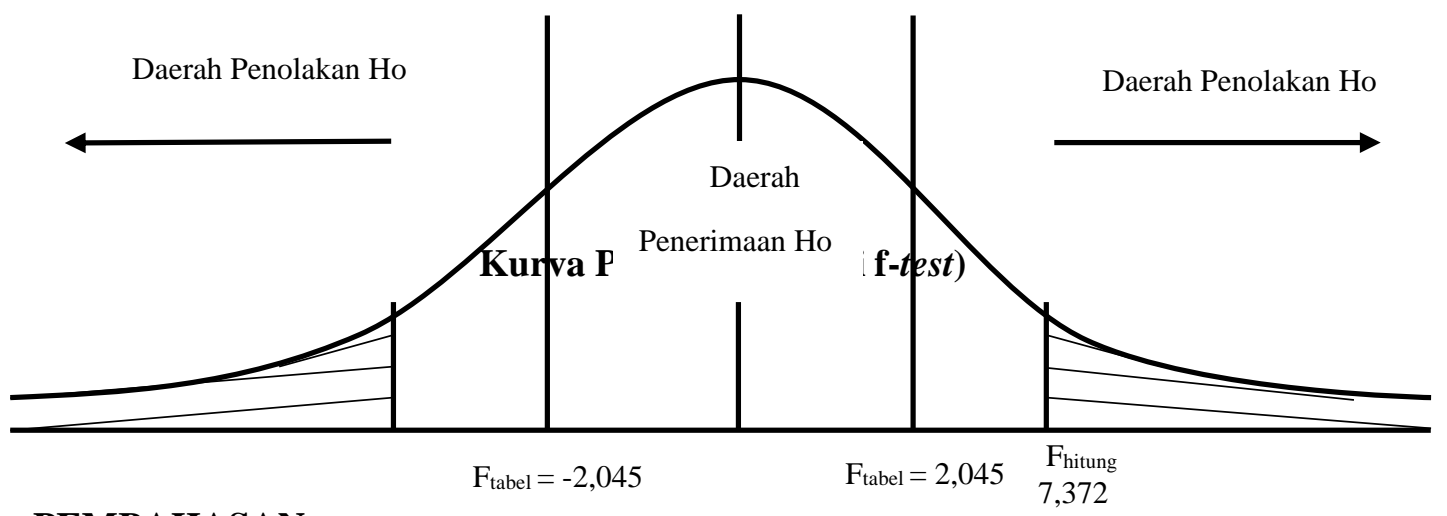

PEMBAHASAN

Pengaruh Return On Asset (ROA) Terhadap Financial Distress

Berikut ini adalah pembahasan hasil penelitian return on asset (ROA) terhadap financial distress :

Hasil uji normalitas data ditunjukkan bahwa besarnya Asymptotic Significanted (2-tailed) sebesar 0,200. Dimana kondisi ini menunjukan bahwa signifikan > 0,05 yang menyatakan bahwa data berdistribusi normal. Hasil analisis koefisien korelasi product moment, besarnya koefisien korelasi antara variabel return on asset (ROA) terhadap financial distress berdasarkan hasil perhitungan yaitu sebesar 0,174 berada pada kategori interval $0,00-0,199$. Hal ini menunjukan antar variabel memiliki tingkat hubungan yang sangat rendah. Berdasarkan hasil analisis uji hipotesis T-test secara parsial return on asset (ROA) memiliki $t_{\text {hitung }}$ sebesar 1,466 dan $t_{\text {tabel }} 2,045$ yang artinya $t_{\text {hitung }} \leq t_{\text {tabel }}(1,466 \leq 2,045)$. Maka dapat disimpulkan bahwa hipotesis $\mathrm{Ha}_{1}$ ditolak dan $\mathrm{Ho}_{1}$ diterima. Sehingga secara statistik dapat dinyatakan bahwa return on asset (ROA) secara parsial tidak terdapat pengaruh terhadap financial distress pada perusahaan Sub Sektor Kimia yang terdaftar di Bursa Efek Indonesia. 
Berdasarkan teori menurut (Hery 2016) menyatakan "return on asset (ROA) adalah rasio yang mengukur tingkat pengembalian dari bisnis atas seluruh aset yang ada. Atau rasio ini menggambarkan efisiensi pada dana yang digunakan dalam perusahaan." Hasil penelitian ini dapat disimpulkan bahwa return on asset (ROA) tidak terdapat pengaruh terhadap financial distress. Hal ini menunjukkan bahwa semakin tinggi rasio ROA yang dihasilkan oleh perusahaan maka semakin rendah kemungkinan terjadinya financial distress. Sebaliknya semakin rendah rasio ROA yang dihasilkan oleh perusahaan menunjukkan kinerja keuangan tidak baik sehingga mengakibatkan profitabilitas menurun dan kemungkinan terjadinya financial distress semakin besar. Hasil penelitian ini sesuai dengan hasil penelitian yang dilakukan oleh (Saifi 2018) yang berjudul Pengaruh Pengaruh Profitabilitas, Likuiditas, dan Leverage terhadap Financial Distress yang menyatakan ROA tidak memiliki pengaruh terhadap Financial Distress.

\section{Pengaruh Ukuran Perusahaan terhadap Financial Distress}

Berikut ini adalah pembahasan hasil penelitian ukuran perusahaan terhadap financial distress :

Hasil uji normalitas data menunjukkan bahwa besarnya Asymptotic Significanted (2-tailed) sebesar 0,200. Dimana kondisi ini menunjukan bahwa signifikan > 0,05 yang menyatakan bahwa data berdistribusi normal. Hasil analisis koefisien korelasi product moment, besarnya koefisien korelasi antara variabel ukuran perusahaan dengan financial distress berdasarkan hasil perhitungan yaitu sebesar 0,537 berada pada kategori interval $0,40-0,599$. Hal ini menunjukan antar variabel ukuran perusahaan dan financial distress memiliki tingkat hubungan yang sedang. Berdasarkan hasil analisis uji hipotesis T-test secara parsial ukuran perusahaan memiliki $t_{\text {hitung }}$ sebesar 3,664 dan $t_{\text {tabel }}$ 2,045 yang artinya $\mathrm{t}_{\text {hitung }} \geq \mathrm{t}_{\text {tabel }}$. Maka dapat disimpulkan bahwa hipotesis $\mathrm{Ha}_{2}$ diterima dan $\mathrm{Ho}_{2}$ ditolak. Sehingga secara statistic dapat dinyatakan bahwa ukuran perusahaan secara parsial terdapat pengaruh positif yang signifikan terhadap financial distress pada perusahaan Sub Sektor Kimia yang terdaftar di Bursa Efek Indonesia.

Berdasarkan teori menurut (Bambang Riyanto 2016) menyatakan "Ukuran perusahaan adalah besar kecilnya perusahaan dilihat dari nilai equity, nilai penjualan, atau nilai aktiva." Ukuran perusahaan menggambarkan seberapa besar total aset yang dimiliki oleh perusahaan tersebut. Perusahaan yang mempunyai total aset yang besar menunjukkan bahwa sinyal yang positif bagi kreditur, sebab perusahaaan akan mudah melakukan diversifikasi dan mampu melunasi kewajiban di masa depan, sehingga perusahaan dapat menghindari terjadinya financial distress. Sedangkan jika perusahaan yang memiliki total aset yang kecil menggambarkan sinyal yang negatif, oleh karena itu akan mengakibatkan perusahaan kurang mampu melunasi kewajiban dan susah menghindari terjadinya financial distress. Hasil penelitian ini sesuai dengan hasil penelitian yang dilakukan oleh (Sopian 2015) yang berjudul Pengaruh Rasio Keuangan dan Ukuran Perusahaan terhadap Financial Distress yang menyatakan terdapat pengaruh Ukuran Perusahaan terhadap Financial Distress.

\section{Pengaruh Return On Asset (ROA) dan Ukuran Perusahaan terhadap Financial Distress}

Berikut ini adalah pembahasan hasil penelitian return on asset (ROA) dan ukuran perusahaan terhadap financial distress :

Hasil analisis korelasi berganda didapatkan nilai $\mathrm{R}$ sebesar 0,581 berada pada kategori interval 0,40 - 0,599 yang menunjukan return on asset (ROA) dan ukuran perusahaan secara simultan memiliki hubungan yang sedang terhadap financial distress pada perusahaan Sub Sektor Kimia yang terdaftar di Bursa Efek Indonesia. Hasil Uji regresi berganda didapatkan persamaan linear $Y=-5,446+0,029 X_{1}+0,263 X_{2}$ yang menunjukan apabila return on asset (ROA) $\left(\mathrm{X}_{1}\right)$ dinaikan 1 satuan, maka financial distress $(\mathrm{Y})$ akan 
mengalami kenaikan sebessar 0,029 dan apabila ukuran perusahaan $\left(X_{2}\right)$ dinaikan 1 satuan, maka financial distress (Y) akan mengalami kenaikan sebesar 0,263. Hasil Analisis Koefisien Determinasi menunjukan bahwa return on asset (ROA) $\left(\mathrm{X}_{1}\right)$ dan ukuran perusahaan $\left(\mathrm{X}_{2}\right)$ terhadap Financial Distress (Y) berpengaruh hanya sebesar 33,7\% sedangkan sisanya sebesar 66,3\% dipengaruhi oleh faktor lainnya yang tidak dimasukkan ke dalam penelitian ini. Berdasarkan hasil analisis uji hipotesis F-test secara simultan return on asset $(\mathrm{ROA})\left(\mathrm{X}_{1}\right)$ dan ukuran perusahaan $\left(\mathrm{X}_{2}\right)$ memiliki $\mathrm{F}_{\text {hitung }}$ sebesar 7,372 dan $F_{\text {tabel }}$ sebesar 2,045 yang artinya $F_{\text {hitung }}>F_{\text {tabel }}(7,372>2,042)$. Maka dapat disimpulkan bahwa hipotesis $\mathrm{Ha}_{3}$ diterima dan $\mathrm{Ho}_{3}$ ditolak. Sehingga secara statistic dapat dinyatakan bahwa return on asset $(\mathrm{ROA})\left(\mathrm{X}_{1}\right)$ dan ukuran perusahaan $\left(\mathrm{X}_{2}\right)$ secara simultan terdapat pengaruh positif yang signifikan terhadap financial distress $(\mathrm{Y})$ pada perusahaan Sub Sektor Kimia yang terdaftar di Bursa Efek Indonesia.

Berdasarkan teori menurut (Sopian 2015) menyatakan "Financial distress adalah kondisi keuangan perusahaan pada tahap penurunan sebelum terjadi likuidasi atau kebangkrutan pada perusahaan". Hal ini dapat disimpulkan bahwa perusahaan tidak mampu mengelola laporan keuangan terutama dalam pengelolaan return on asset (ROA) dan ukuran perusahaan yang kurang efektif dan efisien dikarenakan pada perusahaan Sub Sektor Kimia yang terdaftar di Bursa Efek Indonesia disetiap tahunnya mengalami penurunan dan fluktuasi atau naik turun. Sehingga menyebabkan perusahaan Sub Sektor Kimia yang terdaftar di Bursa Efek Indonesia mengalami kerugian operasional dan kerugian bersih untuk tahun berjalan. Oleh karena itu, pengelolaan laporan keuangan yang baik sangat penting karena akan menghindari kebangkrutan atau financial distress. Hasil penelitian ini sesuai dengan hasil penelitian yang dilakukan oleh (Fridayanthie 2016) yang berjudul Pengaruh Current Ratio, Return On Asset, Ukuran Perusahaan dan Sales Growth terhadap Financial Distress yang menyatakan bahwa return on asset (ROA) dan ukuran perusahaan berpengaruh terhadap financial distress.

\section{KESIMPULAN DAN SARAN}

\section{Kesimpulan}

Berdasarkan identifikasi masalah, hipotesis dan hasil pengujian yang telah dilakukan untuk mengetahui pengaruh Return On Asset (ROA) dan Ukuran Perusahaan terhadap Financial Distress pada Perusahaan Sub Sektor Kimia yang terdaftar di Bursa Efek Indonesia. Berdasarkan hasil analisis dan pembahasan pada bab sebelumnya dapat disimpulkan sebagai berikut:

1. Hasil uji hipotesis secara parsial menunjukkan bahwa tidak terdapat pengaruh antara Return On Asset (ROA) terhadap Financial Distress pada Perusahaan Sub Sektor Kimia yang terdaftar di Bursa Efek Indonesia.

2. Hasil uji hipotesis secara parsial menunjukkan bahwa terdapat pengaruh positif yang signifikan antara Ukuran Perusahaan terhadap Financial Distress pada Perusahaan Sub Sektor Kimia yang terdaftar di Bursa Efek Indonesia.

3. Hasil uji hipotesis secara simultan menunjukkan bahwa terdapat pengaruh positif yang signifikan antara Return On Asset (ROA) dan Ukuran Perusahaan terhadap Financial Saran

Distress pada Perusahaan Sub Sektor Kimia yang terdaftar di Bursa Efek Indonesia.

Berdasarkan hasil kesimpulan di atas maka saran yang dapat diberikan untuk penelitian selanjutnya adalah sebagai berikut:

3. Bagi peneliti selanjutnya, agar memilih sektor perusahaan yang sering mengalami financial distress dan diharapkan dapat menambahkan sampel yang digunakan sehingga mendapat hasil data yang lebih baik.

4. Jangka waktu penelitian dapat diperpanjang dengan memperluas tahun pengamatan agar hasil penelitian lebih dapat menjelaskan hubungan pengaruh dan keakuratan dari 
return on asset (ROA) dan ukuran perusahaan perlu dikembangkan atau diperbanyak lagi.

5. Bagi peneliti selanjutnya, penulis menyarankan agar peneliti menambahkan variabel selain return on asset $\left(\mathrm{X}_{1}\right)$ dan ukuran perusahaan $\left(\mathrm{X}_{2}\right)$, seperti return on investment, return on equity, rasio likuiditas, dan lain-lain. Karena masih terdapat 66,3\% dipengaruhi oleh faktor lainnya yang tidak dimasukkan ke dalam penelitian ini.

\section{DAFTAR PUSTAKA}

Bambang Riyanto. 2016. Dasar-Dasar Pembelanjaan Perusahaan. Yogyakarta: BPFE Yogyakarta.

Berita, Indeks. 2018. "Laba Barito Pacifik turun" 30-31.

Fridayanthie, Eka wida. 2016. "Pengaruh Current Ratio, Return on Asset, Ukuran Perusahaan, Dan Sales Growth Terhadap Financial Distress." IOSR Journal of Economics and Finance 3(1):56.s

Hery. 2016. Analisis Laporan Keuangan Integrated and Comprehensive Edition. Jakarta: PT Grasindo.

Hidayat, Ferrika Sari \&.Sofyan. 2018. "Awal Tahun, Rasio Profitabilitas Buana Finance Merosot."

Meiliana, rakhmat nur hakim \&.diamanty. 2019. "No Title." 17133721.

Saifi, Muhammad. 2018. "PENGARUH PROFITABILITAS, LIKUIDITAS DAN LEVERAGE TERHADAP FINANCIAL DISTRESS ( Studi Pada Perusahaan Food \& Beverage Yang Terdaftar Di Bursa Efek Indonesia Periode 2013-2016 ).” 61(2):11-19.

Sopian, Wiwin Putri Rahayu \&.Dani. 2015. “1), 2).”

Sugiyono, Prof.Dr. 2017. Statistika Untuk Penelitian. Bandung: CV Alfabeta.

Website resmi Bursa Efek Indonesia. https://www.idx.co.id/ (diakses September 2020) 